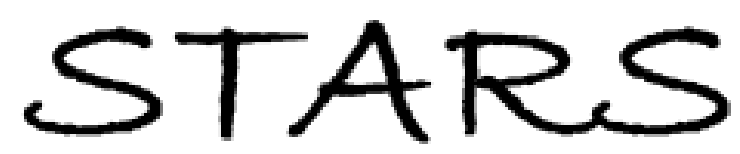

University of Central Florida

STARS

$11-1-2014$

\title{
Occupational Self-Perceptions of Hotel Employees: An Exploratory Study
}

Arie Reichel

Galia Fuchs

Abraham Pizam

University of Central Florida, Abraham.Pizam@ucf.edu

Yaniv Poria

Part of the Hospitality Administration and Management Commons, and the Tourism and Travel Commons

Find similar works at: https://stars.library.ucf.edu/rosenscholar

University of Central Florida Libraries http://library.ucf.edu

This Paper is brought to you for free and open access by the Rosen College of Hospitality Management at STARS. It has been accepted for inclusion in Rosen Faculty Scholarship and Creative Works by an authorized administrator of STARS. For more information, please contact STARS@ucf.edu.

Original Citation

Reichel, A., Fuchs, G., Pizam, A. and Poria, Y., "Occupational Self-Perceptions of Hotel Employees: An Exploratory Study," Tourism Analysis. Vol. 19, No. 5, (2014) pp. 637-641.

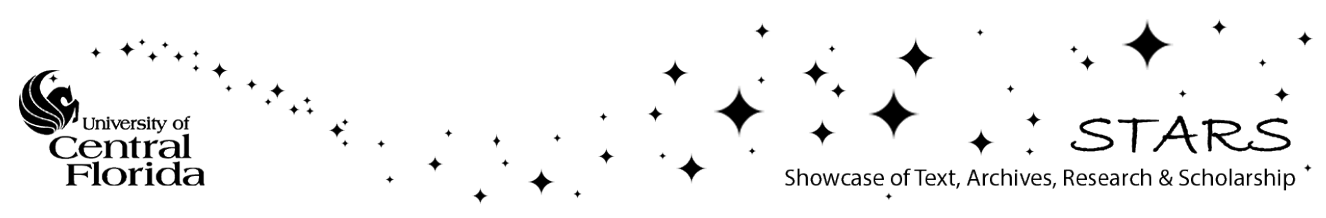




\title{
RESEARCH NOTE
}

\section{OCCUPATIONAL SELF-PERCEPTIONS OF HOTEL EMPLOYEES: AN EXPLORATORY STUDY}

\author{
ARIE REICHEL,* GALIA FUCHS,* ABRAHAM PIZAM,† AND YANIV PORIA* \\ *Hotel and Tourism Management, Ben Gurion University on the Negev, Beer-Sheva, Israel \\ †Rosen College of Hospitality Management, University of Central Florida, Orlando, FL, USA
}

\begin{abstract}
This study aimed to reveal the occupational self-perceptions of rank-and-file employees in the Israeli hotel industry. Due to the exploratory nature of the study a qualitative research approach was adopted. The findings are based on 40 semistructured interviews with current and former Israeli hotel employees. The results revealed that almost all participants had disconcerting negative perceptions of rank-and-file occupations in the Israeli hotel industry. The themes emerged as relevant to the understanding of employees' occupational self-perception were classified into four groups: working conditions, occupational profile, job characteristics and requirements, and moderating factors linked with the reputation of the hotel and hospitality industry as a work environment.
\end{abstract}

Key words: Occupational self-perceptions; Hotel employees; Rank-and-file employees; Israeli hotels

\section{Introduction}

This exploratory study focused on the selfperceptions of Israeli hotel rank-and-file employees about their occupations and the hotel industry in general. These employees are crucial to the hotel operation, having a major impact on the guest experience. In light of their importance to the hotel operation and their job characteristics, one of the most challenging problems the hospitality industry faces is a shortage in quality rank-and-file employees (Morgan, 1982). Research indicates that the problematic image of hotel rank-and-file occupations and the poor and difficult work conditions have a great impact on employment prestige, attractiveness, level of employee pride, organizational citizenship, and eventually on loyalty, turnover, and profitability. Consequently, in numerous cases the hotel industry has high recruitment and training costs as well as poor service quality impacting 
hotels’ profitability (Baum, 2002; Baum, Amoah, \& Spivack, 1997; Bloemer \& Schroder, 2006; Connolly, 2000; Gustafson, 2002; Ladki, 2000; Manning, Davidson, \& Manning, 2005; Pizam, 1982; Pizam \& Thornburg, 2000; Walmsley, 2004; Wood, 1997). However, none of these studies addressed the occupational self-perception and self-image of hospitality employees, whose voice is crucial to the investigation of this topic. It is argued here, that if aiming to explore employees' occupational self-perception image in a valid and reliable way the employees themselves should be provided with a voice to reflect upon it.

\section{Research Objective and Methodology}

The purpose of this study was to uncover the occupational self-perception of rank-and-file hotel employees, recognizing its importance for hotel management policies and for these employees' quality of life. For this exploratory study, a qualitative research design was employed, using in-depth, semistructured interviews that enabled each interviewee to address the issues she/he considered important, while also referring to selected topics that enabled creating a basis for comparison among informants. Aiming for diversity, two sampling techniques were implemented: snowball sampling and theoretical sampling. This combination allowed the researchers to add participants who could contribute additional insights of importance to the study.

In total, 40 rank-and-file participants were interviewed-27 currently employed and 13 former employees in various hotel jobs in different locations throughout Israel — with the intention to get both a current and longer range view of employees' fearfree perspectives of those who are not employed in the hospitality sector. Data analysis was conducted simultaneously with data collection. The notes and transcripts were subjected to thematic content analysis to illuminate underlying themes. Using the "cut and paste technique," the text was organized into themes. Given the inductive nature of this study, the data were analyzed manually. Also, in line with the theoretical assumptions that are at the core of semiotic analysis, attention was assigned to the actual words participants used in the interviews. In the analysis attempts were made to find links between the participants' characteristics (gender, their occupation in the hotel, etc.) and their responses. It should be noted that from the early stages of data collection it was clear that participants had a negative self-image concerning their employment in the hospitality industry and attention was provided to identifying the reasons for this.

\section{Results}

In general, interviewees had a very negative occupational self-perception of employment in the Israeli hotel industry. The themes identified as relevant to conceptualize participants' occupational self-perception were classified into four main groups: working conditions, occupational profile, job characteristics and requirements, and moderating factors linked with the reputation of the hotel and hospitality industry as a working environment. The perceived occupational self-perceptions were not homogenous, varying with factors such as the department within the hotel, hotel type (business vs. resort), and customer characteristics (international tourists vs. local visitors).

\section{Working Conditions}

All 27 participants who are currently employed complained about the low wages that are not commensurate with their hard work. The interviewees referred to issues such as long hours, unexpected additional shifts, and a feeling that their private life is of little interest to management. Participants described their own physical appearance as "tired," "red eyed," and "not neat and tidy," all a result of their long hours on the job. Specifically, housekeeping employees complained about their nonrepresentative and disrespectable appearance, as compared to the front office or security personnel. Some interviewees complained that local (Israeli) guests have high, often nonrealistic service expectations and are disrespectful of the service providers. Participants found this attitude and the resulting behavior as exhibiting a negative image of their work environment and working conditions. Some participants reported that in spite of their negative attitudes toward their working conditions, they were compensated by a feeling of "togetherness" 
or "a warm family" atmosphere, mainly due to the long and nonroutine hours as well as the need to work in a team in which one depends on others. Some participants view the employment in the hotel industry as a "door opener" for better jobs. In addition, the unionized retirement pension was considered a major asset.

\section{Occupational Profile}

Participants often self-associated their harsh working conditions and low salaries with being uneducated, semiskilled employees who cannot find more attractive jobs. Some described their fellow employees as having low motivation and little commitment to the hotel and the hospitality industry. Of more concern was the participants' self-perception that most rank-and-file employees do not have the intellectual ability necessary for higher education. It was also suggested that the hotel working environment is ideal for divorcees, for individuals who are willing to neglect their family life, or those who are displeased with caring for their children.

In Israeli employment policies, the hospitality industry is considered a "preferred industry," meaning that young men and women, honorably discharged from their full term of compulsory military service, receive a special stipend if they work a minimum of 6 consecutive months in it. The interviewees indicated that this unique policy contributes to the industry's image as a carefree, nonchalant, frivolous industry. Furthermore, the presence of illegal migrant workers in Israeli hotels negatively affects the self-perception of the rank-and-file occupations, portraying the hospitality industry as employing only those who have no other job opportunities.

\section{Job Characteristics and Requirements}

The study revealed a hierarchy of prestige associated with various departments and jobs within a hotel. Front-office and security personnel were considered as having higher skills and nonmonotonous tasks, enabling the individual "to think," "improvise," and "make decisions." Front-office employees were also perceived as responsible, and as having social skills as well as computer skills, and as individuals who know how to react under pressure. All these attributes highly contributed to their image. Housekeeping, on the other hand, was considered as the least skilled job. In this context the issue of the employees' appearance and specifically the uniforms was raised as a signifier of the employees' status.

In general, the interviewees assigned demeaning images to custodial jobs, especially those performed in the hotel's public areas. Jobs that involve cleaning and especially in the presence of the hotel guests were depicted as appropriate for marginal groups, including migrant workers and minorities who are willing to do "humiliating" Sisyphean "dirty" cleaning chores as they had no other option for making a living.

\section{Moderating Factors Linked to the Reputation of the Hotel and Hospitality Industry}

Employees self-perception varied according to factors such as the hotel's attributes and the image of the chain brand, with better reputation meaning higher occupational self-perception of hotel employment. Business hotels in major cities had a more positive image than resort hotels located in the periphery. Also, working in renowned international hotel chains was perceived as more respectable than working in local Israeli hotel chains, suggesting that the former are managed according to high international standards that are more professional than the local ones. It should be noted that there were few individual hotels — managed by Israeli chains - that had a very positive image as a work environment, and these hotels were portrayed as the exception, not the rule. Participants argued that these hotels benefit from a unique guest mix and very high service standards, and employees working in these hotels have a very positive occupational self-perception.

Another element explaining the occupational self-perception of rank-and-file employees was related to ageism. A few interviewees associated older age with poor self-perception: the younger the employee, the more his/her employment in the hotel industry was perceived as "respectable" and "socially acceptable." Employees who spent their entire career in the hotel industry were often viewed as "inept, lacking skills, and unable to find more 
respectable jobs.” Also the hotel location affected the employees' occupational self-perception. Being employed in resort destinations was associated with "young employees preoccupied with sex and drugs in a fun atmosphere" while employment in big cities was considered more respectable, serious, and professional. Regarding resort destinations the issue of sexism also surfaced, with interviewees claiming that rank-and-file females were often perceived as "cheap," and were frequently exposed to unpleasant sexual comments from guests. The above unexpected moderating factors are highlighted in the discussion section in light of their significant impact on employees’ self-perceptions.

\section{Discussion and Conclusion}

The results of this exploratory study indicated that, for the most part, current and former rankand-file employees have a negative occupational self-perception of employment in the Israeli hotel industry. The study revealed four themes related to employees' self-perception: working conditions, occupational profile, job characteristics and requirements, and moderating factors linked with the reputation of the hotel and hospitality industry as a work environment.

Exploring the rank-and-file workers' perceptions of their employment in the hotel industry in Israel reveals that they share common issues with hotel industry employees elsewhere, including feelings of subservience, inconvenient working hours, and low wages (Baum, 2002; Pizam, 1982; Walmsley, 2004; Wood, 1997). The current study also discovered the significance of employees' appearance. The results clearly support previous studies (Nickson, Warhurst, \& Dutton, 2005; Rafaeli \& Pratt, 1993; Yeh et al., 2003) that revealed employees perceived business attire to be more respectable in comparison to other dress codes.

As noted earlier, participants' self-perceptions of their employment and themselves was associated with varying degrees of status attributed to different occupations within the hotel. Within each hotel there is a hierarchy of occupational images and statuses where custodial and housekeeping jobs are perceived to be the least prestigious and carry the lowest status; front-desk and security jobs were perceived to be the most prestigious and hold the highest status, mainly because they carry responsibility and independent decision making (Lundberg, Gudmundson, \& Andersson, 2009). Business hotels had a better occupational image than resort hotels, perhaps because most of the guests are international business people who seem to be a preferable clientele, especially vis-à-vis local guests "who want everything immediately and on the spot." As indicated in previous studies (Pizam, 1982), it seems that one should not underestimate the positive aspects that were mentioned, such as family atmosphere and a well-organized industry-wide pension plan, which affect employees' occupational self-perception.

This study focuses on personal interviews of employees concerning their self-perceptions rather than the general public. This may explain why some of the findings reported here are new to the literature. For example, the findings revealed that there is a link between employees' self-perception and their level of exposure to the "customer gaze." Specifically, those employees who are exposed to the hotel guest while doing manual blue-collar jobs, such as cleaning, have the worst occupational image. Moreover, the government policy of granting the hotel industry a "preferred status" for hiring recently discharged soldiers was mentioned as a factor negatively affecting employees' selfperception. Inappropriate sexual behavior toward female employees by guests in resort hotels was also an issue raised by the interviewees. As for ageism, the participants' overall perception was that older employees in the hotel industry are "losers" who could not get a better job. The aforementioned findings highlight the importance of carefully studying employees' self-reports rather than simply the industry' image among the general population.

\section{Limitations, Future Research, and Implications for Management}

This qualitative exploratory study was conducted in Israel, and given its interpretive nature and small sample its generalizability cannot be assured. It is clear that a quantitative cross-cultural study is needed to capture the hospitality rank-and-file self-perceptions (Hoffman, Johnson, \& Lefever, 2000). More future research should investigate 
various methods which, based on this study's findings, could be utilized to have a positive impact on employees' self-image. In such studies there is a need to consider the department one is enrolled in. For example, issues such as pay raise or empowering by enriching ones' job description may have different meanings for employees assigned to the different hotel departments, which in turn will impact employee's self-image.

Nevertheless, the results clearly indicate that Israeli hotels should act to improve their employees' occupational self-perception. In line with this study's findings some suggestions are made. First, employees should be provided with the feeling that their actual acting on the job is of great importance to the organization. Second, because housekeeping employees indicated that a contact with the guest has a positive impact on their self-image, they should be encouraged to have some interaction with the guests rather than being "transparent." Third, hotels should take into account that international clientele have a positive impact on employees' self- image. Fourth, hotel management should take into account the negative impact of the "guest gaze," encouraging conducting certain chores in the hotel during night shifts. Fifth, although "the guest is always guest," adopting some codes of conduct for guests in resort hotels might be considered to prevent employees' sexual harassments. It should be noted, however, that the aforementioned suggestions are relevant to the Israeli context only. In other environments in situ research is needed prior to any specific recommendation.

The findings reported here may be relevant for other service-related organizations such as restaurants or for occupations such as airplane attendants who share some similarities with hotel occupations. Again, further research is needed and generalizations should not be made unless thoroughly investigating employees' self-image in situ.

\section{References}

Baum, T. (2002). Skills and training for the hospitality sector: A review of issues. Journal of Vocational Education and Training, 54(3), 343-364.

Baum, T., Amoah, V. S., \& Spivack, S. (1997). Policy dimensions of human resource management in the tourism and hospitality industries. International Journal of Contemporary Hospitality Management, 9(5/6), 221-229.

Bloemer, J., \& Schroder, G. O. (2006). The role of employee relationship proneness in creating employee loyalty. International Journal of Bank Marketing, 24(4), 252-264.

Connolly, M. (2000). Human resource management in the Ireland: Industry's challenge during a period of unprecedented growth. In S. M. Hoffman, C. Johnson, \& M. M. Lefever (Eds.), International hospitality human resource management (pp. 85-93). New York: American Hotel \& Motel Association Publishing Co.

Gustafson, C. M. (2002). Employee turnover: A study of private clubs in the USA. Journal of Contemporary Hospitality Management, 14(3), 106-113.

Hoffman, S. M., Johnson, C., \& Lefever, M. M. (2000). International hospitality human resource management. New York: American Hotel \& Motel Association Publishing Co.

Ladki, S. M. (2000). Human challenges facing the Lebanese hospitality industry. In S. M. Hoffman., C. Johnson., \& M. M. Lefever (Eds.), International hospitality human resource management (pp. 173-180). New York: American Hotel \& Motel Association Publishing Co.

Lundberg, C. A., Gudmundson, A., \& Andersson, T. D. (2009). Herzberg's two-factor theory of work motivation tested empirically on seasonal workers in hospitality and tourism. Tourism Management, 30(6), 890-899.

Manning, L. M., Davidson, M., \& Manning R. L. (2005). Measuring tourism and hospitality employee workforce perceptions. International Journal of Hospitality Management, 24(1), 75-90.

Morgan, W. J. (1982). Equality vs inequality amongst hospitality workers. International Journal of Hospitality Management, 1(3), 157-162.

Nickson, D., Warhurst, C., \& Dutton, E. (2005). The importance of attitude and appearance in the service encounter in retail and hospitality. Managing Service Quality, 15(2), 195-208.

Pizam, A. (1982). Tourism manpower: The state of the art. Journal of Travel Research, 21(2), 5-9.

Pizam, A., \& Thornburg, S. W. (2000). Absenteeism and voluntary turnover in Central Florida hotels: A pilot study. International Journal of Hospitality Management, 19(2), 211-217.

Rafaeli, A., \& Pratt, M. (1993). Tailored meanings: On the meaning and impact of organizational dress. Academy of Management Review, 18(1), 32-55.

Walmsley, A. (2004). Assessing staff turnover: A view from the English Riviera. International Journal of Tourism Research, 6(4), 275-287.

Wood, R. C. (1997). Working in hotels and catering. London: International Thomson Business Press.

Yeh, R., Tu, Y. T., Chuang, N. K., Ming-Ji, J., Lin, M. J. J., \& Lin, H. J. T. (2013). Hotel employees' uniform and their self-perceptions in Southern California. Tourism Management Perspectives, 6, 79-81. 